\title{
Principles of Administrative and Legal Regulation of Ukrainian Space Defense
}

\author{
Oksana Ivanik \\ Ph.D. student, Research Institute of Public Law (Kyiv, Ukraine) \\ E-mail: oksanazubko2018@gmail.com \\ https://orcid.org/0000-0002-7695-499X
}

The paper describes the principles of administrative and legal regulation of Ukrainian Space Defense. The author outlined and considered: 1) general principles - characteristic for administrative-legal regulation both for the activities of public administration entities; 2) special principles - specific for Ukrainian Space Defense, and subjects of administration of Ukrainian Space Defense. The general principles brought by: the rule of law and rule of law; independence; priority rights and freedoms of man and citizen; humanity, justice and equality to society. The special principles by classified: scientific; planning; conformity of methods, forms and procedures of administrative activity of subjects of public administration to the functions and tasks of Ukrainian Space Defense; stimulating subjects of public administration for effective management companies operating in Ukrainian Space Defense; strategic management of the export of objects of Ukrainian Space Defense; balanced development of Ukrainian Space Defense; the effectiveness of Ukrainian Space Defense; optimality; Innovation; the concentration of Ukrainian Space Defense on priority directions of development; integrity of approaches to defining the state's defense needs; access to defense projects of a wide range of Ukrainian entities of all forms of ownership; high qualifications and professional competences of public administration officials of enterprises of Ukrainian Space Defense; development of the principles of self-sustainment of enterprises of Ukrainian Space Defense; a combination of publicity and secrecy in Ukrainian Space Defense.

Keywords: Ukrainian Space Defense; administrative activity; administrative regulation; National security; defense industrial complex; subjects of public administration.

\section{Принципи адміністративно-правового регулювання космічної оборони України}

\section{Іваник, Оксана Михайлівна}

\author{
Здобувач наукового ступеня кандидата юридичних наук \\ Науково-дослідного інституту публічного права
}

(Київ, Україна)

В статті розкрито принципи адміністративно-правового регулювання космічної оборони України. Автором виокремлені та розглянуті: 1) загальні принципи - характерні для адміністра-

(C) Ivanik, Oksana, 2018 
тивно-правового регулювання як для діяльності суб’єктів публічної адміністрачії; 2) спеціальні принципи - характерні для космічної оборони України, та суб'єктів адміністрування космічноі оборони Украӥни. До загальних приниипів автор віднесла: верховенство права та законності; незалежність; пріоритет прав і свобод людини та громадянина; гуманізм, справедливість та рівність усіх перед суспільством. До спеціальних приниипів автор віднесла: науковість; плановість; відповідність методів, форм і процедур адміністративної діяльності суб'єктів публічного адміністрування функиіям та завданням космічної оборони Украӥни; стимулювання суб'єктів публічної адміністрачії до ефективного адміністрування підприємств, щзо прачюють на космічну оборону Украйни; стратегічне управління експортом об'єктів космічної оборони Украйни; збалансований розвиток космічної оборони України; ефективність космічної оборони України; оптимальності; інноваційності; концентрацію космічної оборони України на пріоритетних напрямах розвитку; иілісність підходів до визначення оборонних потреб держави; доступ до оборонних проектів широкого кола украӥнських суб 'єктів господарювання всіх форм власності; високі кваліфікаційні здібності та професійні компетениії посадових осіб публічної адміністраиії підприємств космічної оборони України; розвиток засад самоокупності підприємств космічної оборони України; поєднання публічності та секретності в галузі космічної оборони Украӥни.

Ключові слова: космічна оборона України; адміністративна діяльність; адміністративне регулювання; начіональна безпека; оборонно-промисловий комплекс; суб 'єкти публічної адміністрації.

Received: January 24, 2018; accepted: February 26, 2018

Advanced Space Law, Volume 1, 2018: 57-65.

https://doi.org/10.29202/asl/2018/1/7

\section{Вступ}

Принципи права - наукова категорія, яка завжди викликала інтерес учених у сфері як теорії права, так і галузевих правових наук. Принципи права мають безпосередній зв'язок з переважною більшістю стрижневих загальнотеоретичних питань, як-то: сутність права, норма права, юридичний акт, правова система, правове регулювання тощо. Вони пов'язують право з політикою, економікою, мораллю, забезпечують єдність різних правових процесів, форм, теорій, ідей і концепцій, понятійно-категоріальних рядів [Колодій, 1998: 3; Погребняк, 2006].

Принципи адміністративно-правового регулювання космічної оборони України $є$ основними ідеями, якими повинна керуватися вся військово-оборонна система органів публічного адміністрування у своїй діяльності. Саме тому принципи космічної оборони України потребують першочергового дослідження.

До розкриття принципів адміністративно-правового регулювання оборонно-промислового комплексу України, до складу якого належить космічна оборона, звертали свою увагу такі вчені як В. Авер'янов, Ю. Битяк, Ю. Ведєрніков, В. Галунько, Т. Ганзицька, П. Діхтієвський, А. Колодій, О. Кузьменко, В. Курило, М. Марченко, В. Молдован, І. Невзоров, С. Погребняк, А. Пухтецька, В. Семенов, В. Сорокин, О. Старчук, С. Стеценко, Ю. Тихомиров, М. Чабаненкота інші.

Проте, вищевказані вчені розкрили особливості принципів адміністративно-правового регулювання, а проблематика космічної оборони України потребує нових викликів в сучасних реаліях суспільства. 
Мета статті полягає в тому, щоб на базі дослідження та аналізу позицій вчених-юристів, основ законодавства, визначити принципи адміністративно-правового регулювання космічної оборони України.

\section{Виклад основних положень}

Теоретики права вважають, що принципи права — це об'єктивно властиві праву відправні начала, незаперечні вимоги (позитивні зобов'язання), які ставляться до учасників суспільних відносин із метою гармонічного поєднання індивідуальних, групових і громадських інтересів. Іншими словами, це $є$ своєрідна система координат, в рамках якої розвивається право, i одночасно вектор, який визначає напрямок його розвитку. Принципи $€$ підставою права, містяться у його змісті, виступають як орієнтири у формуванні права, відбивають сутність права та основні зв'язки, які реально існують у правовій системі. В принципах зосереджено світовий досвід розвитку права, досвід цивілізації [Скакун, 2001: 45].

Професор Юрій Битяк окреслює, що «принципами права» є вихідні, об’єктивно зумовлені основоположні засади, відповідно до яких формується й функціонує система та зміст галузі права. За межами соціальної активності і практичної діяльності суб'єктів принципи адміністративного права не можуть бути сформовані й закріплені, а тим більше реалізовані [Адміністративне право, 2007: 64].

Ігор Невзоров зазначає, що «принципи права» — це такі відправні ідеї існування права, які виражають найважливіші закономірності й основи цього типу держави і права, $€$ однопорядкові з сутністю права і становлять його основні риси, відрізняються універсальністю, вищою імперативністю і загальною значимістю, відповідають об'єктивній необхідності побудови та вдосконалення певного суспільного ладу [Невзоров, 2003: 75].

Микола Чабаненко вважає принципами права основоположні, вихідні засади (як нормативно закріплені, так і ні), що визначають характер та напрямки правового регулювання суспільних відносин. Принципам права, як визначальній правовій категорії, притаманні певні властивості, риси, що дозволяють їх відмежовувати від інших правових явищ [Чабаненко, 2013: 115].

3 позиції Володимира Семенова, принципи діяльності прийнято визначати як основоположні начала, що обумовлені тією роллю, яку вони відіграють в існуванні та розвитку права. Практично принципи діяльності визначають самостійність тієї чи іншої роботи, тому вони висловлюють сутність конкретної поведінки. На їх основі відбувається побудова всіх інших норм, інститутів, які не можуть суперечити принципам. Принципи $€$ якісними особливостями, соціально-юридичною спрямованістю тієї чи іншої діяльності [Семенов, 2012: 23].

Тетяна Ганзицька під принципами права розуміс об'єктивно зумовлені природою даного державно організованого суспільства нормативно-керівні, формально закріплені у зовнішніх джерелах права імперативні ідеї, котрі виражають цінності, притаманні даній системі права, визначають загальну спрямованість правового регулювання суспільних відносин з метою гармонічного поєднання інтересів (індивідуальних, групових, громадських) їх учасників [Ганзицька, 2014: 24].

Михайло Марченко трактує принципи права як [Марченко, 1996: 143]:

1. Основні ідеї, вихідні положення процесу його формування, розвитку і функціонування; 
2. Конструкції, на засадах яких встановлюються і функціонують не тільки норми, інститути або галузі, але і вся правова система;

3. Сферу правосвідомості, правової ідеології і науки;

4. Визначення, що будуються на аналізі різниці понять принципів права і правових принципів.

На думку Марченка, правові принципи - це головні ідеї, які виражають основні вимоги до системи права тієї чи іншої держави [Марченко, 1996].

Оксана Старчук переконана, що принципи права — це такі засадничі ідеї права, які визначають зміст і спрямованість його норм та характеризуються системністю, взаємоузгодженістю, загальнообов'язковістю, універсальністю, стабільністю, предметною визначеністю, загальнозначущістю й регулятивністю [Старчук, 2012: 43].

На думку В. Сорокіна, «принципи права» із суто юридичної точки зору - не є правилами поведінки, але мають загальнообов'язковий характер. 3 принципів права можна вивести необхідне, але поки що не закріплене, правило поведінки. Принципи права надають , таким чином, безпосередню регулюючу дію на суспільні відносини, будучи тією правовою базою, на основі якої відбувається формування конкретного правила для вирішення справи [Сорокин, 2002: 72].

Щодо принципів адміністративного права, то професор Валентин Галунько, під принципами адміністративного права визначає основні вихідні, об'єктивно зумовлені засади, на яких базується діяльність суб'єктів адміністративного права, забезпечуються права та свободи людини і громадянина, нормальне функціонування громадянського суспільства та держави [Адміністративне право, 2015: 47].

Отже, принципи адміністративного права — це вихідні засади, якими керуються у своїй діяльності суб'єкти публічної адміністрації, визначається політика держави в певній галузі, формується механізм правового регулювання, з метою виконання завдань та функцій адміністративного права, захисту прав, свобод та законних інтересів осіб.

Варто сказати про особливості принципів. Характерними рисами принципів адміністративного права є такі [Адміністративне право, 2015a: 39-40]:

1) Вони формуються з метою забезпечення прав і свобод людини та громадянина й нормального функціонування громадянського суспільства та держави;

2) Визначають найбільш загальні й стабільні вимоги, що сприяють їх утвердженню та захисту суб'єктами публічної адміністрації, визначають характер адміністративного права і напрямки його подальшого розвитку;

3) Установлюють керівні засади-настанови, що визначають найважливіші правила, за якими здійснюється та зорганізується діяльність суб'єктів адміністративного права;

4) Принципи адміністративно права характеризуються прогресивністю, засвідчують ідеальні для умов сучасності основоположні засади поведінки суб'єктів адміністративного права, які є реально досяжними.

Відносно систематизації принципів, то до загальних принципів адміністративного права відносять: - принцип законності; - принцип пріоритету прав та свобод людини і громадянина; - принцип рівності громадян перед законом; - принцип демократизму нормотворчості й реалізації права; — принцип взаємної відповідальності держави і людини; - принцип гуманізму і справедливості у взаємовідносинах між державою і людиною [Авер'янов, 2011: 82] 
На думку Юрія Битяка, спеціально-галузевими принципами адміністративного права $\epsilon$ : - служіння органів виконавчої влади та їх апарату суспільству й людині; — обмеженість втручання органів виконавчої влади в громадське й особисте життя людини; - повнота прав і свобод громадян в адміністративно-правовій сфері; - взаємна відповідальність; - визначення мінімально необхідних повноважень органів державної виконавчої влади; - оптимальне доповнення й урівноваження державно-владних повноважень органів виконавчої влади з повноваженнями органів самоврядування [Адміністративне право, 2007: 33].

Валентин Галунько виділяє наступні загальні принципи адміністративних процедур: верховенства права - основоположний принцип здійснення адміністративних процедур, закріплений у ст. 8 Конституції України; законності - формування та здійснення адміністративних процедур мають будуватись на суворій відповідності вимогам чинного законодавства; системності - держава намагається створити чітку та зрозумілу систему адміністративних процедур, елементами якої є суб'єкт публічного адміністрування, до якого має можливість звертатися фізична чи юридична особа; неупередженості та безсторонності адміністративної процедури - при вирішенні адміністративної справи не допускається будь-яка неправомірна заінтересованість суб'єкта публічного адміністрування в результатах такого розгляду; оптимізації адміністративних процедур - адміністративна процедура здійснюється найменш витратним, найбільш економним шляхом; правової визначеності - зводиться до ясності й недвозначності практики здійснення адміністративних процедур, оскільки інше не може забезпечити іï однакове застосування, не виключає необмеженості трактування у правозастосовній практиці й неминуче призводить до сваволі; підконтрольності - полягає в існуванні в державі системи контрольних органів і відповідних механізмів, які дозволяють ефективно контролювати порядок здійснення адміністративних процедур і за потреби коригувати дії безпосередніх виконавців; пріоритетності прав і свобод людини - передбачає обов'язок суб'єкта публічного адміністрування в конкретній ситуації, в кожному випадку виходити передусім з найбільш прийнятного для заявника рішення; презюмованої правомірності правової позиції заявника - принцип, відповідно до якого особа, яка подає заяву, вважається такою, що має нормативно визначені підстави для можливості звернення, а розгляд індивідуальної справи та підготовка адміністративного акта відбуваються з акцентом на сутність викладеного прохання заявника [Адміністративне право, 2015а: 208].

Врахувавши вищевказані позиції, на наш погляд, принципи адміністративно-правового регулювання космічної оборони України слід поділити на:

1) Загальні принципи — характерні для адміністративно-правового регулювання як для діяльності суб’єктів публічної адміністрації;

2) Спеціальні принципи - характерні для космічної оборони України, та суб’єктів адміністрування космічної оборони України.

До загальних принципів слід віднести: верховенство права та законності; незалежність; пріоритет прав і свобод людини та громадянина; гуманізм, справедливість та рівність усіх перед суспільством.

Відносно спеціальних принципів, то тут треба враховувати специфіку організації космічної оборони України. Вона складається з підприємств оборонно-промислового комплексу України, та підприємств підпорядкованих Державному космічному агентству України. 
Проект Закону про національну безпеку України визначає поняття «оборонно-промисловий комплекс України» як сукупність органів державного управління, підприємств, установ і організацій промисловості та науки, що розробляють, виробляють, модернізують і утилізують продукцію військового призначення, виконують послуги в інтересах оборони для оснащення та матеріального забезпечення сил безпеки і сил оборони, а також здійснюють постачання товарів військового призначення та подвійного використання, надання послуг військового призначення під час виконання заходів військово-технічного співробітництва України з іншими державами [Проект Закону, 2015].

В структурі Міністерства оборони України створено Управління інформаційних технологій. Серед основних завдань Управління є «розробка концептуальних основ державної космічної політики в частині, пов'язаній зі створенням та використанням космічної техніки військового призначення, а також разом із Державним космічним агентством України - космічної техніки подвійного призначення (використання)» [Управління, 2017]. Управління використовує можливості оборонно-промислового комплексу України та Державного космічного агентства України.

В Україні всі підприємства оборонно-промислового комплексу обєднані в державний концерн «Укроборонпром». Відповідно Статуту державного концерну «Укроборонпром» учасниками Концерну є державні підприємства, зазначені у додатку до Статуту [Статут, 2015]. Серед них підприємства що працюють на космічну оборону України. Наприклад,

1. Державне підприємство Науково-виробничий комплекс «Прогрес», сфера діяльності якого - оборонна та авіаційно-космічна промисловість.

2. Казенне підприємство «Науково-виробничий комплекс «Іскра», що спеціалізується на розробці та виробництві наземної радіолокаційної техніки цивільного та військового призначення.

3. Державне підприємство «Львівський державний завод «Лорта», що задіяний у розробці космічної техніки.

Крім підприємств що входять до складу державного концерну «Укроборонпром», на космічну оборону України працюють підприємства що входять до складу Державного космічного агентства України. Серед основних завдань Державного космічного агентства відсутні завдання створення та використання космічної техніки військового призначення. Основними завданнями Державного космічного агентства $\epsilon$ [Державне, 2019]:

1. Забезпечення формування і реалізація державної політики у сфері космічної діяльності;

2. Надання підтримки в підготовці та реалізація міжнародних проектів у сфері дослідження та використання космічного простору.

Але всі підприємства, що входять до складу Державного космічного агентства фактично працюють на космічну оборону України. Наприклад,

1. Державне підприємство «Виробниче об'єднання Південний машинобудівний завод ім. О. М. Макарова» - провідне українське підприємство із виробництва ракетно-космічної техніки та технологій оборонного, наукового та народногосподарського призначення;

2. Державне конструкторське бюро «Південне» ім. М. К. Янгеля, що спеціалізується на розробці бойових ракетних комплексів та ракетно-космічних систем. 
3. Державне підприємство «Укркосмос», серед основних завдань якого є: забезпечення потреб в передачі та обробці інформації органів державного управління та організацій, діяльність яких пов'язана з інтересами національної безпеки України;

4. Публічне акціонерне товариство «Хартрон», що входить до переліку підприємств, що мають стратегічне значення для економіки і безпеки України.

5. Казенне підприємство спеціального приладобудування (КП СПБ) «Арсенал», яке $\epsilon$ провідним розробником і виробником оптичних і оптико-електронних приладів для космічної, авіаційної та наземної техніки військового і цивільного призначення в Україні.

Враховуючи зміст категорії «оборонно-промисловий комплекс», а також завдання державного концерну «Укроборонпром» та Державного космічного агентства України, на наш погляд, до спеціальних принципів адміністративно-правового регулювання космічної оборони України слід віднести наступні засади:

1. Науковість;

2. Плановість;

3. Відповідність методів, форм і процедур адміністративної діяльності суб'єктів публічного адміністрування функціям та завданням космічної оборони України;

4. Стимулювання суб'єктів публічної адміністрації до ефективного адміністрування підприємств, що працюють на космічну оборону України;

5. Стратегічне управління експортом об’єктів космічної оборони України;

6. Збалансований розвиток космічної оборони України;

7. Ефективність космічної оборони України;

8. Оптимальності;

9. Інноваційності;

10. Концентрацію космічної оборони України на пріоритетних напрямках розвитку;

11. Цілісність підходів до визначення оборонних потреб держави;

12. Доступ до оборонних проектів широкого кола українських суб'єктів господарювання всіх форм власності;

13. Високі кваліфікаційні здібності та професійні компетенції посадових осіб публічної адміністрації підприємств космічної оборони України;

14. Розвиток засад самоокупності підприємств космічної оборони України;

15. Поєднання публічності та секретності в галузі космічної оборони України.

\section{Висновки}

Усе вищевикладене дає підстави вважати, що:

1. Принципи адміністративного права - це вихідні засади, якими керується у своій діяльності суб’єкти публічної адміністрації, визначається політика держави в певній галузі, формується механізм правового регулювання, з метою виконання завдань та функцій адміністративного права, захисту прав, свобод та законних інтересів осіб;

2. Принципи адміністративно-правового регулювання космічної оборони України слід поділити на: загальні принципи - характерні для адміністративно-правового регулювання як для діяльності суб’єктів публічної адміністрації; спеціальні 
принципи - характерні для космічної оборони України та суб'єктів адміністрування оборонно-промислового комплексу.

3. До загальних принципів слід віднести: верховенство права та законності; незалежність; пріоритет прав і свобод людини та громадянина; гуманізм, справедливість та рівність усіх перед суспільством;

4. До спеціальних принципів слід віднести: науковість; плановість; відповідність методів, форм і процедур адміністративної діяльності суб'єктів публічного адміністрування функціям та завданням космічної оборони України; стимулювання суб'єктів публічної адміністрації до ефективного адміністрування підприємств, що працюють на космічну оборону України; стратегічне управління експортом об'єктів космічної оборони України; збалансований розвиток космічної оборони України; ефективність космічної оборони України; оптимальності; інноваційності; концентрацію космічної оборони України на пріоритетних напрямках розвитку; цілісність підходів до визначення оборонних потреб держави; доступ до оборонних проектів широкого кола українських суб' єктів господарювання всіх форм власності; високі кваліфікаційні здібності та професійні компетенції посадових осіб публічної адміністрації підприємств космічної оборони України; розвиток засад самоокупності підприємств космічної оборони України; поєднання публічності та секретності в галузі космічної оборони України.

\section{Література}

Авер'янов, Вадим. Вибрані наукові праці. Київ: Інститут держави і права ім. В. М. Корецького НАН України, 2011.

Адміністративне право Украӥни. За ред. Ю. П. Битяка. Київ: Юрінком Інтер, 2007.

Адміністративне право України: навчальний посібник. За редакцією Валентина Галунька. Том 1. Загальне адміністративне право. Херсон: Грінь Д.С., 2015.

Адміністративне право Украӥни. Повний курс: підручник. За редакцією Валентина Галунька. Херсон: ОЛДІ-ПЛЮС, 2015а.

Ганзицька, Тетяна. Теоретико-правовий аналіз поняття принципів права. Науковий вісник Академії муніципального управління. Серія: Право. 2, 2014: 19-24.

Державне космічне агентство України. 2019. http://www.nkau.gov.ua/ua/

Колодій, А. М. Принциипи права України. Київ, 1998.

Марченко, Михаил. Теория государства и права. Москва: Юридическая литература, 1996.

Невзоров, Ігор. Принщип законності в правозастосувальній діяльності. Дисертація канд. юрид. наук: 12.00.01 Національний ун-т внутрішніх справ. Х., 2003.

Погребняк, С. Втілення принципів права в юридичних актах. Вісник Академії правових наук України. 2 (45), 2006: 21-32.

Проект Закону про національну безпеку України. Верховна Ради України, 2015. http:// w1.c1.rada.gov.ua/pls/zweb2/webproc4_1?pf3511=63531

Семенов, Володимир. Конституционные принципь гражданского судопроизводства. Москва: Юридическая литература, 2012.

Скакун, О. Ф. Теорія держави і права: підручник. Харків: Консум, 2001.

Сорокин, В. В. Судебная практика как источник права: за и против. Сибирский юридический вестник. 3, 2002: 20-25. 
Статут Державного кониерну «Укроборонпром»: затверджений постановою Кабінету Міністрів України від 31.08.2011 № 993. Укроборонпром: офіційний веб-портал. 2015. http://ukroboronprom.com.ua/uk/pro-kontsern/dokumenty

Старчук, Оксана. Щодо поняття принципів. Часопис Київського університету права. 2, 2012: 40-43.

Управління інформаційних технологій. 2017. http://www.mil.gov.ua/ministry/strukturaaparatu-ministerstva/uit.html

Чабаненко, Микола. Поняття принципів аграрного права. Науковий вісник Дніпропетровського державного університету внутрімніх справ. 4, 2013: 110-116.

\section{References}

Aver'ianov, Vadym. Vybrani naukovi pratsi. Kyiv: Instytut derzhavy i prava im. V.M. Koretskoho NAN Ukrainy, 2011.

Administratyvne pravo Ukrainy. Za red. Yu. P. Bytiaka. Kyiv: Yurinkom Inter, 2007.

Administratyvne pravo Ukrainy: navchalnyi posibnyk. Za redaktsiieiu Valentyna Halunka. Tom 1. Zahalne administratyvne pravo. Kherson: Hrin D.S., 2015.

Administratyvne pravo Ukrainy. Povnyi kurs: pidruchnyk. Za redaktsiieiu Valentyna Halunka. Kherson: OLDI-PLIuS, 2015a.

Hanzytska, Tetiana. Teoretyko-pravovyi analiz poniattia pryntsypiv prava. Naukovyi visnyk Akademii munitsypalnoho upravlinnia. Seriia: Pravo. 2, 2014: 19-24.

Derzhavne kosmichne ahentstvo Ukrainy. 2019. http://www.nkau.gov.ua/ua/

Kolodii, A. M. Pryntsypy prava Ukrainy. Kyiv, 1998.

Marchenko, Mykhayl. Teoryia hosudarstva y prava. Moskva: Yurydycheskaia lyteratura, 1996.

Nevzorov, Ihor. Pryntsyp zakonnosti v pravozastosuvalnii diialnosti. Dysertatsiia kand. yuryd. nauk: 12.00.01 Natsionalnyi un-t vnutrishnikh sprav. Kh., 2003.

Pohrebniak, S. Vtilennia pryntsypiv prava v yurydychnykh aktakh. Visnyk Akademii pravovykh nauk Ukrainy. 2 (45), 2006: 21-32.

Proekt Zakonu pro natsionalnu bezpeku Ukrainy. Verkhovna Rady Ukrainy, 2015. http:// w1.c1.rada.gov.ua/pls/zweb2/webproc4_1?pf3511=63531

Semenov, Volodymyr. Konstytutsyonnыe pryntsypb hrazhdanskoho sudoproyzvodstva. Moskva: Yurydycheskaia lyteratura, 2012.

Skakun, O. F. Teoriia derzhavy i prava: pidruchnyk. Kharkiv: Konsum, 2001.

Sorokyn, V. V. Sudebnaia praktyka kak ystochnyk prava: za y protyv. Sybyrskyi yurydycheskyi vestnyk. 3, 2002: 20-25.

Statut Derzhavnoho kontsernu «Ukroboronprom»: zatverdzhenyi postanovoiu Kabinetu Ministriv Ukrainy vid 31.08.2011 № 993. Ukroboronprom: ofitsiinyi veb-portal. 2015. http://ukroboronprom.com.ua/uk/pro-kontsern/dokumenty

Starchuk, Oksana. Shchodo poniattia pryntsypiv. Chasopys Kyivskoho universytetu prava. 2, 2012: 40-43.

Upravlinnia informatsiinykh tekhnolohii. 2017. http://www.mil.gov.ua/ministry/strukturaaparatu-ministerstva/uit.html

Chabanenko, Mykola. Poniattia pryntsypiv ahrarnoho prava. Naukovyi visnyk Dnipropetrovskoho derzhavnoho universytetu vnutrishnikh sprav. 4, 2013: 110-116. 